\title{
Invasions of alien woody plant taxa across a cluster of villages neighbouring the Mlyňany Arboretum (SW Slovakia)
}

\author{
Peter Ferus", Peter Hot'ka, Dominika Košútová, Jana Konôpková \\ Mlyňany Arboretum, Institute of Forest Ecology of the Slovak Academy of Sciences, \\ Vieska nad Žitavou 178, 95152 Slepčany, Slovakia
}

\begin{abstract}
Ferus, P., HoŤKa, P., Košútová, D., KonôPKová, J., 2020. Invasions of alien woody plant taxa across a cluster of villages neighbouring the Mlyňany Arboretum (SW Slovakia). Folia Oecologica, 47 (2): 121-130.

Ornamental plantations in cities and particularly botanical gardens and arboreta are rich sources of alien flora. Mlyňany Arboretum, established in 1892, cultivates 1049 non-native woody plant species on the area of 67 ha. In this work we answered following questions: 1. How many taxa are spontaneously spreading in the arboretum and how is the spreading intensity related to their ecological demands and reproduction traits? 2. How many taxa appear behind the fence? 3. How far from the arboretum they can get? 4. Do private gardens and historical aristocratic park in the studied village cluster contribute to species escapes from culture? 5. Which from the widely spread taxa can represent future risk of invasiveness on the national level? We found that about one tenth of taxa spread across the arboretum (particularly Cotoneaster spp., Prunus laurocerasus, P. serotina and Quercus rubra) and number of their seedlings corresponded only with the mother plant number. Almost one third of these species left the arboretum and their seedlings were observed in distance up to $500 \mathrm{~m}$ from the village (mainly Mahonia aquifolium, P. serotina). Private gardens were a large source of $J u$ glans regia seedlings, frequency of which decreased with the distance from villages (no species escaped from the historical park). Weed risk assessment revealed potential invasion danger only for Amorpha fruticosa.
\end{abstract}

\section{Keywords}

arboretum, escape from culture, historical park, village cluster, weed risk assessment

\section{Introduction}

Horticulture represents an important pathway for new plant invasions (e.g. Dehmen-Schmutz et al., 2007; Hulme et al., 2008; PYŠEK et al., 2011). Proportion of neophytes (mostly woody plants) in urban flora of city Plzeň (Czech Republic) grew three times (up to $17 \%$ ) over the 120 years (CHOCHOLOUŠKová and PYšEK., 2003). Later analysis carried out by Lososoví et al. (2012) in 32 central European cities revealed $34 \%$ neophytes in average, particularly with North-American origin, which were growing presumably in their residential areas. However, this percentile dramatically decreased along the urban-rural gradient besides relatively common secondary releases of ornamental plants, provided by gardeners, bridging the natural barriers (KOWARIK, 2005 and references therein).

As communicated by Guo et al. (2018), nowadays domestic gardens play a dominant role in selecting alien species with adaptive strategies that facilitate naturalisation. Using the identified local naturalisation thresholds

*Corresponding author: e-mail:peter.ferus@savba.sk 
of climatic suitability and global naturalisation frequency, and climate projections for the years 2050 and 2070, MAYR et al. (2017) identified 45 garden-plant species (out of total 954 species) that are currently not naturalised in Radolfzell (Germany) but are likely to become so in the future. Recently, KŘIVÁNEK and PYŠEK (2008) brought an overview of non-native ornamental woody plant species in the neighbouring Czech Republic and based on a broad dataset for each, they identified attributes associated with their success. From 1,617 analysed species, only 135 were escaping from culture and 52 had status 'naturalised'. Seventeen of the naturalised species were considered as invasive and 11 from them as pests.

However, what is the role of botanical gardens (BGs) in the alien plant naturalisation process? Besides they represent the key player in the global plant conservation through their living collections of endangered species, long-term archiving of seeds, taxonomic training and public outreach, much less acknowledged is their role in both deliberate and accidental introduction of invasive alien plants across the globe. Furthermore, they might be a source of alien escapes to the adjacent natural environment, intentional or unintentional spread by local trading and exchange with other BGs through the Index Seminum initiative. Although, progressive shift to the conservation activities and native flora has been seen in some BGs, only $10 \%$ variability of the alien plant richness across regions can be explained by the presence of BGs in the regional scale (Hulme, 2011). Recent rise in number and importance of Asian botanical gardens combined with increasing emphasis on horticulture and breading research in these institutions and a significant role of retail-plant sales suggest horticulture-driven plant invasions from Asia in the future (vAN KLEUnen et al., 2018).

Mlyňany Arboretum was founded in 1892 by a Hungarian aristocrat, Dr. István Ambrózy-Migazzi, as an extraordinary experiment with the aim to create an evergreen park. In the socialistic era it became a large research institute (Institute of Dendrobiology, Centre for Bio-Ecological Sciences of the Slovak Academy of Sciences), which significantly enlarged its living collections, particularly by means of collecting expeditions to China and North Korea (nowadays 1933 taxa; HoŤKA and BARTA, 2012). Decades ago it joined the Index Seminum exchange, offering propagules of 300-600 species (FerUs et al., 2017b). Simultaneously, arboretum has produced plant material for city greeneries and sold plantlets for park visitors (ca. 150 taxa).

There are numerous examples of botanical gardens with spontaneously spreading/escaping plant species in the surroundings (e.g. SCHMIDT, 2001; BomanOwSKA et al., 2012; SHYNDER, 2019). In this work, we intend to investigate, how many taxa are spontaneously spreading in the arboretum and how is the spreading intensity related to their ecological demands and reproduction traits, how many taxa appear behind the fence, how far from the arboretum they can get, whether private gardens and historical aristocratic park in the studied village cluster contribute to species escapes from culture, and which from the widely spread taxa can represent future risk of invasiveness on the national level.

\section{Materials and methods}

\section{Characterization of the study area}

The study area (Fig. 1) is located in the cadastre of four villages, Tesárske Mlyňany, Vieska nad Žitavou, Slepčany and Nová Ves nad Žitavou, which are situated in the southwestern Slovakia, on the northern edge of the Podunajská nížina Lowland (the Pohronská pahorkatina Hills), in the Žitava river alluvium (agricultural landscape). Height above the sea level of the undulating terrain ranges in interval of $150-200 \mathrm{~m}$. The area belongs to of the warmest and driest regions of Slovakia. For more detailed information on local climate, see the Walter-Gaussen diagram (Fig. 2) and our former work (FERUs et al., 2017a). Concerning the soil quality, the study area comprises gleyic eutric fluvisols, haplic luvisols and stagni-haplic luvisols (www.podnemapy.sk; GRANEC and ŠURINA, 1999). Details on the soil types in the arboretum could be found in POLLÁKOvá et al. (2017).

\section{Field research}

In autumn 2018, whole area of the Mlyňany Arboretum (of 67 ha; HoŤKA and BARTA, 2012), urbanised area of Vieska nad Žitavou, Slepčany (regular village) and Nová Ves nad Žitavou (village with a 6.6 ha large historical aristocratic park from the second half of the 19th century; TOMAŠKO, 2004) as well as adjacent and more distant bio-corridors (abandoned vineyards, forests, river banks, balks) connecting these villages (a three-village cluster), were surveyed for frequency of occurrence (by order of magnitude) of non-native woody plant species (except for those already taken as invasive (MEDVECKÁ et al., 2012)), which spontaneously spread in the parks or evidently escaped from culture. Bio-corridors were divided in 2 groups: 1 . with radius up to $500 \mathrm{~m}$ and 2. those with radius in range $500-1,000 \mathrm{~m}$ from the village edge. In case of vegetatively reproducing species, each stem was accepted as an individual. Age of the seedlings was not of interest.

\section{Gathering of the data from databases}

Species (nomenclature taken from BENČAŤ (1982)) spreading in the area of the Mlyňany Arboretum were analysed for the number of mother individuals in the park, shade tolerance (Plant for a Future, www.pfaf.com; Missouri Botanical Garden, www.missouribotanicalgarden.org), principal mode of propagule spreading (Pladias - Database of Czech Flora and Vegetation, www.pladias.cz) and thousand seed weight (TSW; WALTER, 2011; Royal Botanical Gardens, Kew, www.data.kew.org), and linear regressions (Pearson's regression coefficients) with the seedling number were drawn (input for the principal spreading mode was potential distance, which can be reached by a propagule using this mode: barochory - metres, anemochory tens of metres, zoochory - hundreds of metres). Tree and shrub species present in hundreds or thousands in any location of the three-village cluster were characterized in respect of their taxonomy and geographical origin (REHDER, 


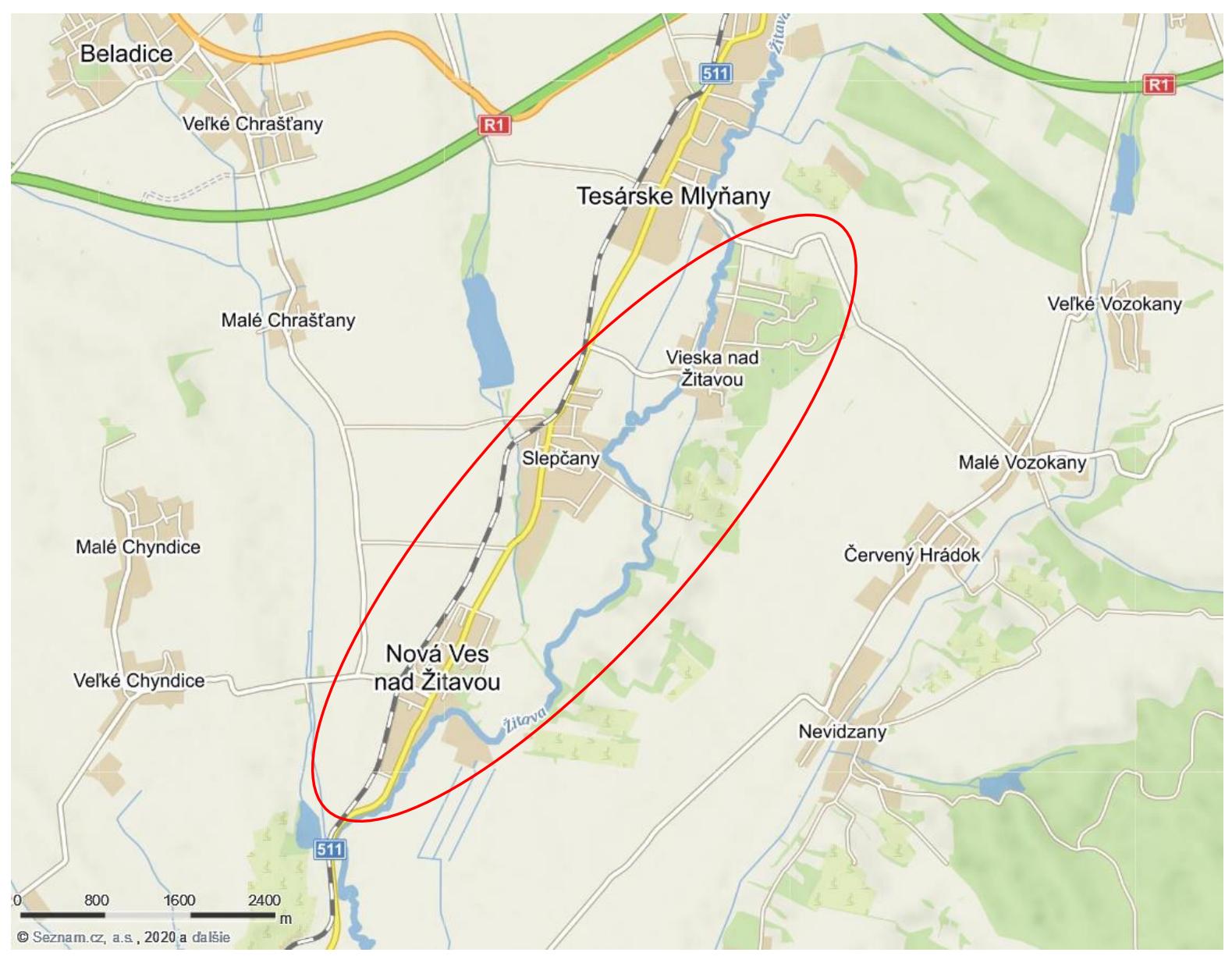

Fig. 1. Studied village cluster, comprising Vieska nad Žitavou with the Mlyňany Arboretum, Nová Ves nad Žitavou with the historical aristocratic park and a regular village Slepčany (www.mapy.cz).

1954), residential time (year of the first introduction; BENČǍ̆, 1982), past or present planting frequency (own experience), reproduction mode and propagule spreading vector (Pladias - Database of Czech Flora and Vegetation, www.pladias.cz), species requirements for light, water and soil (Plant for a Future, www.pfaf.com), preferred EUNIS habitats (Pladias - Database of Czech Flora and Vegetation, www.pladias.cz; Global Biodiversity Information Facility, www.gbif.com; Global Invasive Species Database, www.iucngisd.org) and present ecological status in Slovakia (MedveckÁ et al., 2012).

\section{Assessment of species invasiveness on the national level}

Finally, these widely spread woody plant species were tested for potential to became an invasive species on the national level using a standard prediction procedure based on the cumulative scoring of climatic match with the native range of distribution, life history in the new area, habitat preferences, growth and reproduction characteristics as well as persistence attributes of respective species - weed risk analysis (WRA, PHELoung et al., 1999; Ǩ̌IVÁNEK and PYŠEK, 2006).

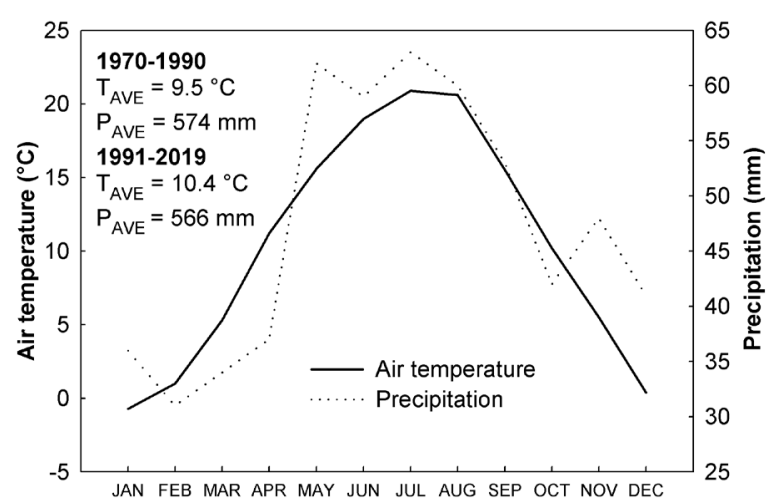

Fig. 2. Walter-Gaussen climatic diagram of the studied area as derived from meteorological observations carried out in the Mlyňany Arboretum during the past almost thirty years (1991-2019), considered as being under the influence of global warming (FAšKO et al., 2008). Furthermore, there are averages of yearly temperature and precipitation for periods 1970-1990 (normal) and 1991-2019, embedded. 


\section{Results}

Altogether seedlings of 108 woody plant taxa were found in the understorey of adult trees and shrubs of the Mlyñany Arboretum collection (Table 1). Although most of them spread in a few individuals (41 taxa) or tens of individuals (53 taxa), the more important were those found in hundreds and thousands. Hundreds of seedlings established following species: Acer cappadocicum, Berberis series julianae and wallichianae, Elaeagnus umbellata, Ilex aquifolium, Laburnum anagyroides, Lonicera maackii, Mahonia aquifolium, Pinus armandii, Quercus aliena and Viburnum rhytidophyllum. Thousands of offspring produced Cotoneaster species, Prunus laurocerasus, Prunus serotina and Quercus rubra.

Most of taxa, seedlings of which were more-or-less widely spreading in the arboretum, had only a few (almost $52 \%$ ) or tens of mother plants (ca. 39\%; Fig. 3). Major part of species tolerates shade (approx. 66\%), is spreading by barochory and zoochory (ca. $38 \%$ each), and produces propagules of TSW approx. $5 \mathrm{~g}, 20 \mathrm{~g}$ and $50 \mathrm{~g}$ (each of ca. $20 \%$ ). However, the only one parameter medium strongly correlated with seedling number was the mother plant number $(\mathrm{r}=0.498)$.

On the other hand, urbanised area of Vieska nad Žitavou was relatively poor on woody plants escaping from culture (Table 2). There were only five species, widely appearing there (tens of individuals), namely: Acer saccharinum,
Juglans regia, Parthenocissus inserta and Prunus serotina. However, in distance up to 500 from the village, 28 taxa escaping from the arboretum and adjacent abandoned area for ornamental woody plant production (formerly belonging to a cooperative farm), were identified (only a few individuals of each). Larger but mostly local infestation of the bio-corridors was caused by Acer buergerianum, A. saccharinum, Amorpha fruticosa, Fraxinus pennsylvanica, Lonicera maakii, Rhus potaninii, Rhodotypos scandens. A massive invasion of the neighbouring forest, vegetation along Žitava River, abandoned vineyards and balks was provided by Juglans regia, Mahonia aquifolium and Prunus serotina. However, frequency of Juglans regia decreased with distance from the village margin.

Urbanised area of the rest villages (Slepčany and Nová Ves nad Žitavou) revealed occasional escapes of several woody plant species (Table 3 and 4). Among more often found species belong Rhus typhina and particularly Juglans regia, frequency of which was reduced with distance from the villages. Historical aristocratic park in Nová Ves nad Žitavou was not a source of escaping alien woody plants.

Only one from eighteen woody plant species in the three-village cluster, occurring in hundreds and more seedlings, was indicated as potentially invasive for Slovakia by the weed risk analysis (WRA; Table 5). Amorpha frutico$s a$ represents a North-American shrub from the Fabaceae family, which was first introduced to the area of present

Table 1. Alien woody plant species spontaneously spreading in the Mlyňany Arboretum with the level of their occurrence

\begin{tabular}{|c|c|}
\hline Species & $\begin{array}{l}\text { Seedling number } \\
\text { (order of magnitude) }\end{array}$ \\
\hline $\begin{array}{c}\text { Acer buergerianum, A. cissifolium, A. sinense, A. theiferum, Ampelopsis brevipedunculata, } \\
\text { Buddleia lindleyana, Caragana arborescens, Catalpa ovata, Cephalotaxus harringtonii, } \\
\text { Cercidophyllum japonicum, Deutzia scabra, Eonymus alatus, Ehretia thyrsiflora, Forsythia } \\
\text { ovata, F. viridissima, Gymnocladus dioica, Hamamelis } \times \text { intermedia, Juglans ailanthifolia, J. } \\
\text { nigra, Ligustrum obtusifolium, L. ovalifolium, Lonicera vesicaria, L. fragrantissima, L. } \times \\
\text { purpusii, L. morrowii, L. standishii, Maclura pomifera, Malus sieboldii, Morus nigra, Orixa } \\
\text { japonica, Paulownia tomentosa, Philadelphus sp., Pinus nigra, Ptelea trifoliata, Rhamnus utilis, } \\
\text { Ruscus aculeatus, Securinega suffruticosa, Spiraea miyabei, S. henryi/wilsonii, S. thunbergii, } \\
\text { Zelkova serrata }\end{array}$ & $10^{0}$ \\
\hline $\begin{array}{l}\text { Abies sachalinenis, A. grosseri, A. monspessulanum, A. saccharinum, Akebia quinata, Amorpha } \\
\text { fruticosa, Berberis series Vulgares, Broussonetia papyrifera, Buxus sempervirens, Calocedrus } \\
\text { decurens, Castanea sativa, Colutea orientalis, Cryptomeria japonica, Cudrania tricuspidata, } \\
\text { Diospyros lotus, Fontanesia fortunei, Forsythia suspensa, Juglans mandshuricum, J. regia, } \\
\text { Juniperus spp., Koelreuteria paniculata, Ligustrum quihoui, L. sinense, L. tschonoskii, } \\
\text { Liriodendron chinensis, L. tulipifera, Lonicera japonica, Parthenocissus inserta, Physocarpus } \\
\text { opulifolius, Pinus strobus, P. wallichiana, Pterocarya fraxinifolia, P. } \times \text { rehderiana, Pyracantha } \\
\text { coccinea, Quercus acutissima, Rhodotypos scandens, Rhus potaninii, R. radicans, R. typhina, R. } \\
\text { verniciflua, Ribes alpinum, R. fasciculatum, R. petraeum/rubrum, Rosa multiflora, Sorbaria } \\
\text { tomentosa, Spiraea japonica, Symphoricarpos albus, Syringa oblata, Thuja occidentalis, T. } \\
\text { orientalis, T. plicata, Ulmus parvifolia, Vitis riparia }\end{array}$ & $10^{1}$ \\
\hline $\begin{array}{l}\text { Acer cappadocicum, Berberis series Wallichianae, Elaeagnus umbellata, Ilex aquifolium, } \\
\text { Laburnum anagyroides, Lonicera maackii, Mahonia aquifolium, Pinus armandii, Quercus } \\
\text { aliena, Viburnum rhytidophyllum }\end{array}$ & $10^{2}$ \\
\hline Cotoneaster spp., Prunus laurocerasus, Prunus serotina, Quercus rubra & $10^{3}$ \\
\hline
\end{tabular}




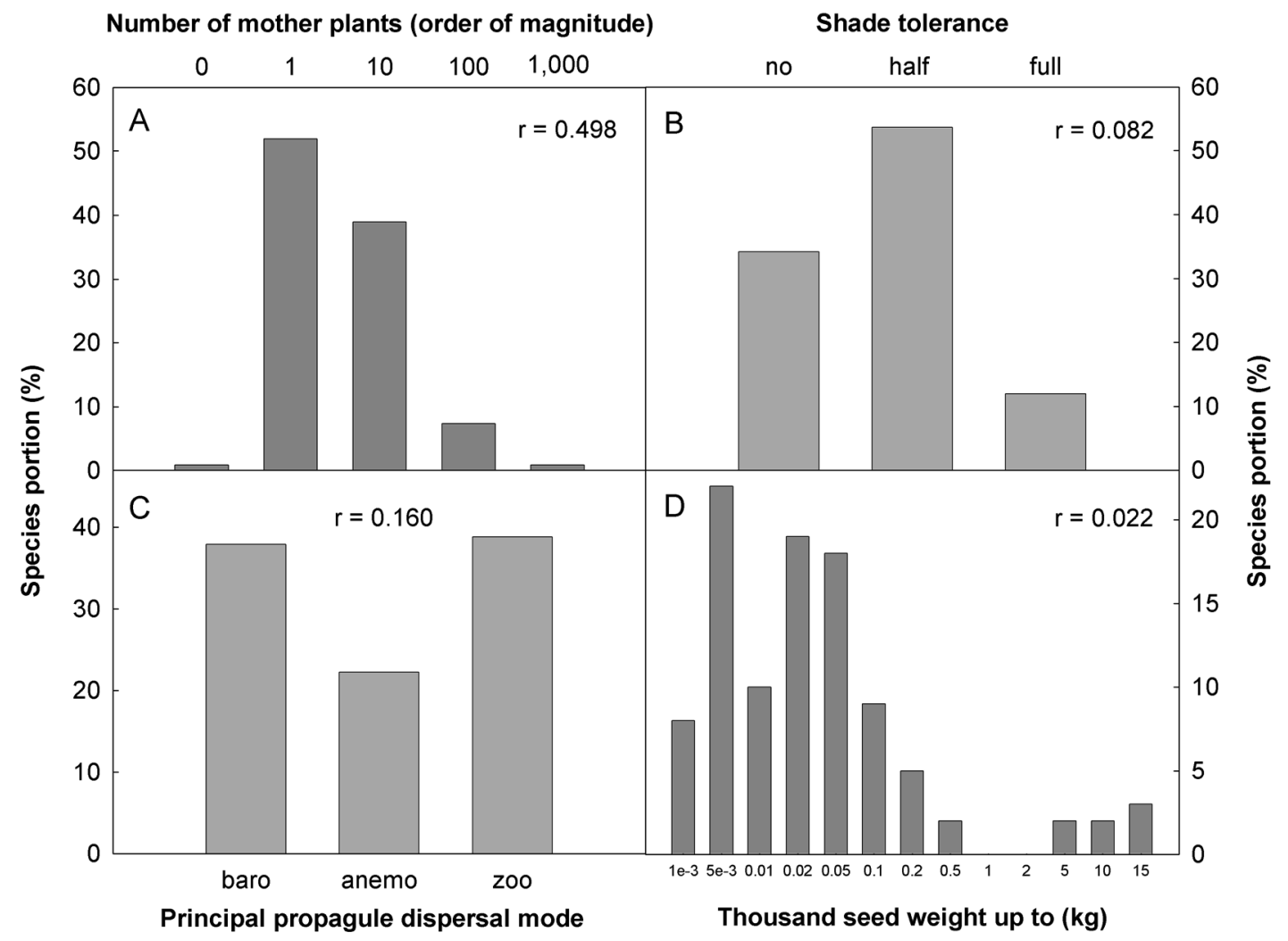

Fig. 3. Categorisation of alien woody plant species spreading in the Mlyňany Arboretum by number of mother plants (A), shade tolerance (B), principal propagule dispersal mode (C) and thousand seed weight (D) with Pearson's regression coefficients (r) of these parameters to the seedling number.

Table 2. Alien tree and shrub species spreading in the urbanised area of Vieska nad Žitavou as well as in adjacent forest, along the Žitava River, in abandoned vineyards and balks in radius up to 500 and $1,000 \mathrm{~m}$ from the village margin

\begin{tabular}{lc}
\hline Species & $\begin{array}{c}\text { Seedling number } \\
\text { (order of magnitude) }\end{array}$ \\
\hline
\end{tabular}

Urbanised area

Hibiscus syriacus, Morus alba, Prunus persica

Forests, river banks and balks up to $500 \mathrm{~m}$

Berberis series Vulgares, Castanea sativa, Cornus stolonifera, Cotoneaster spp.,

Elaeagnus angustifolia, Ilex aquifolium, Juglans nigra, Juniperus spp., Ligustrum obtusifolium,

Lonicera fragrantissima, Morus alba, M. nigra, Parthenocissus inserta, Phellodendron

amurense, Physocarpus opulifolius, Pinus armandii, P. nigra, Pleioblastus simonii, Prunus

persica, Ptelea trifoliata, Quercus rubra, Rhus verniciflua, Ribes fasciculatum, Rosa multiflora,

Spiraea chamaedryfolia, Symphoricarpos albus, Thuja occidentalis, Viburnum rhytidophyllum

Acer buergerianum, A. saccharinum, Amorpha fruticosa, Fraxinus pennsylvanica, Lonicera maakii, Rhus potaninii, Rhodotypos scandens

Juglans regia, Mahonia aquifolium

Abandoned vineyards, river banks, balks up to $1,000 \mathrm{~m}$ 
Slovakia in 1850 and because of its resistance to urban/industrial environment widely planted in the socialistic era. It reproduces generatively and is spread by Earth gravity and animals. This species tolerates half shade, drought and poor soils because of symbiotic nitrogen fixation. In the Middle Europe, it spreads in forests and anthropogenic habitats. We rank it as naturalised in Slovakia. Since obtaining WRA values near 6 , further species should be taken under consideration for invasiveness: Juglans regia, Mahonia aquifolium, Prunus serotina and Rhus typhina.

\section{Discussion}

Similar to the Mlyňany Arboretum, where $10.3 \%$ allochtonous trees and shrubs (particularly Cotoneaster spp., Prunus laurocerasus, P. serotina and Quercus rubra) propagate spontaneously across the park, ScHMIDT (2001) recorded 115 spreading from total 1,640 taxa in Buda Arboretum of the Szent István University, Budapest, Hungary. Many Cotoneaster species belonged to the most established ones, too. NAGODă et al. (2014) found 45 from 195 analysed foreign species able to form progeny in Dimitrie Brandza Botanical Garden of the University of Bucharest, Romania. Although most of the species spontaneously spreading in Botanical Garden of the

Table 3. Alien woody plant species spreading in the urbanised area of Slepčany as well as in abandoned vineyards along the Žitava River and balks in radius up to 500 and $1,000 \mathrm{~m}$ from the village margin

\begin{tabular}{|c|c|}
\hline Species & $\begin{array}{c}\text { Seedling number (order } \\
\text { of magnitude) }\end{array}$ \\
\hline \multicolumn{2}{|c|}{ Urbanised area } \\
\hline $\begin{array}{c}\text { Castanea sativa, } \\
\text { Cotoneaster spp., Mahonia } \\
\text { aquifolium, Prunus persica, } \\
\text { Syringa vulgaris, Vitis } \\
\text { riparia }\end{array}$ & $10^{0}$ \\
\hline Juglans nigra & $10^{1}$ \\
\hline Juglans regia, Rhus typhina & $10^{2}$ \\
\hline \multicolumn{2}{|c|}{ Forests, river banks and balks up to $500 \mathrm{~m}$} \\
\hline $\begin{array}{c}\text { Acer saccharinum, Aesculus } \\
\text { hippocastanum, Juglans } \\
\text { nigra, Morus alba }\end{array}$ & $10^{0}$ \\
\hline Juglans regia & $10^{2}$ \\
\hline \multicolumn{2}{|c|}{$\begin{array}{l}\text { Abandoned vineyards, river banks, } \\
\text { balks up to } 1000 \mathrm{~m}\end{array}$} \\
\hline $\begin{array}{c}\text { Castanea sativa, Prunus } \\
\text { persica }\end{array}$ & $10^{0}$ \\
\hline Juglans regia, Rhus typhina & $10^{1}$ \\
\hline
\end{tabular}

Table 4. Alien tree and shrub species spreading in the historical aristocratic park and urbanised area of Nová Ves nad Žitavou as well as those escaped to river banks and balks in radius up to $500 \mathrm{~m}$ from the village edge

\begin{tabular}{cc}
\hline Species & $\begin{array}{c}\text { Seedling number } \\
\text { (order of magnitude) }\end{array}$ \\
\hline Historical aristocratic park & - \\
$-\quad$ Urbanised area & $10^{0}$ \\
$\begin{array}{c}\text { Juglans nigra, Morus alba, } M . \\
\text { nigra, Parthenocissus inserta, } \\
\text { Prunus persica, Vitis riparia }\end{array}$ & $10^{1}$ \\
Symphoricarpos albus & $10^{2}$ \\
Juglans regia & \\
River banks and balks up to $500 \mathrm{~m}$ \\
Juglans regia
\end{tabular}

University of Łódź, Poland were native and herbaceous, Juglans regia and Mahonia aquifolium represented those of allochtonous dendroflora (BomANOwsKA et al., 2012). Inside the M. M. Gryshko National Botanical Garden of the NAS of Ukraine in Kiev, spontaneously spread $22 \%$ of taxa but only $3.1 \%$ crossed boundaries of the botanical garden (SHYNDER, 2019).

As presented in Fig. 2, number of seedlings observed in the Mlyňany Arboretum is not related to the species shade tolerance, principal propagule dispersal vector and TSW. Only the mother plant number appeared more important for this parameter. Seedling establishment success (naturalisation in the local scale) of a species is a complex trait combining its acclimation level, genetic diversity, propagule pressure and effective dispersal (THEOHARIDES and DuKes, 2007).

Our survey of bio-corridors up to $500 \mathrm{~m}$ around Vieska nad Žitavou revealed 38 non-native woody plant taxa escaped from culture (most of them coming from the arboretum). More precisely, only $29.6 \%$ from the cultivated allochtonous woody plant taxa spontaneously spreading in the Mlyňany Arboretum, appeared behind the fence. Prunus serotina and Mahonia aquifolium belong to the most abundant species. There are many works referring to the massive proliferation of the former one in the European forests (e.g. GoDEFroID et al., 2005; SCHRADER and StARFIngER, 2009; HalarewiCZ and ZolniERZ, 2014). BENČAŤOvá et al., (2013) first described occurrence of Mahonia aquifolium in the Robinia pseudoacacia forest in the neighbourhood of the arboretum. However, this species has been spontaneously spreading in the urban environment and forests of numerous European countries (e.g. KOWARIK, 2005; ZeRBe, 2007; KŘIVÁNEK and PYŠEK, 2008; ELIÁš, 2017).

The only one recent work comming from the arboretum with similar objectives TOMAŠKo (1999) referred to 


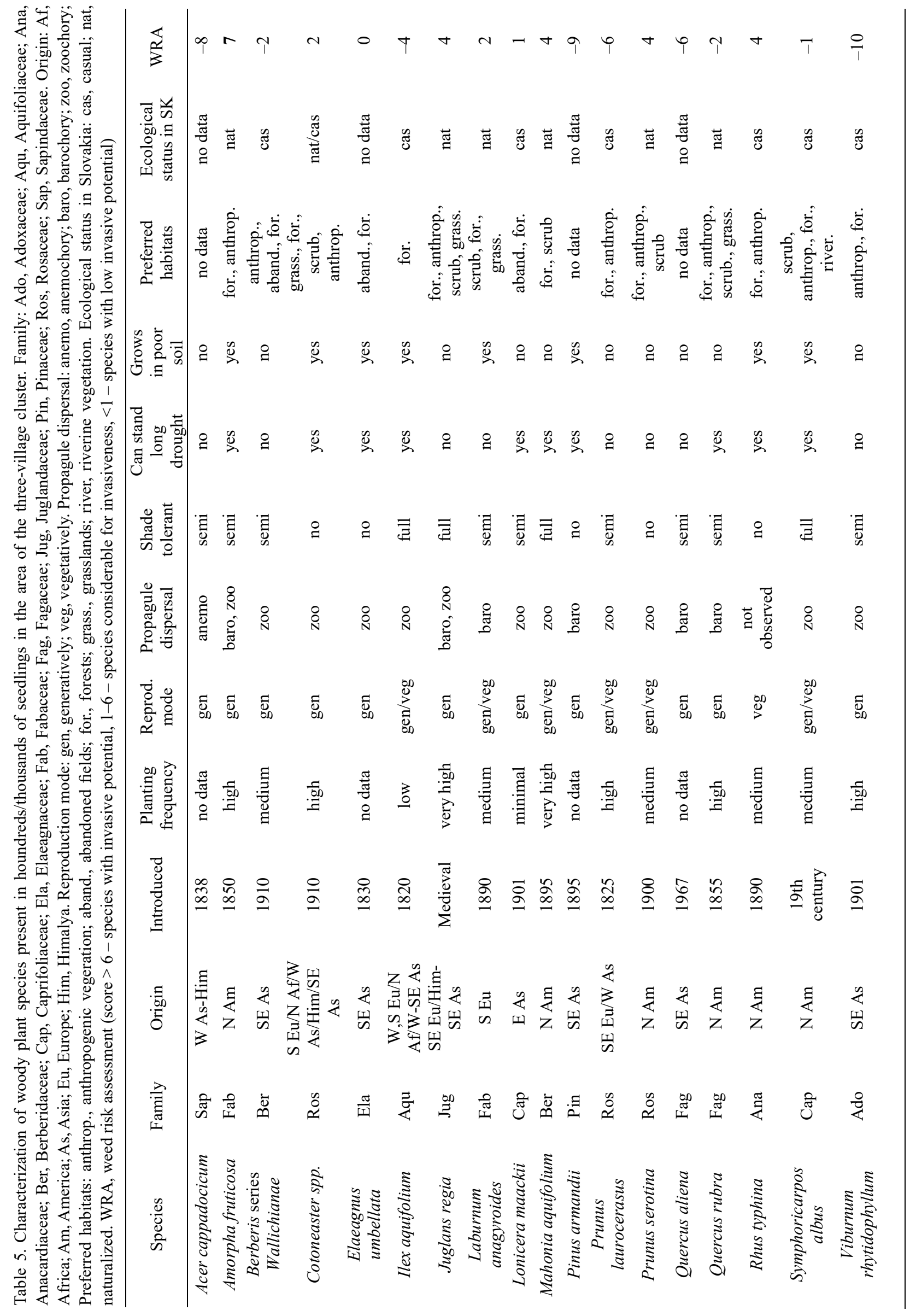


appearance of Acer negungo, Ailanthus altissima, Fraxinus pennsylvanica, Ilex aquifolium, Paulownia tomentosa and Prunus laurocerasus in the above mentioned Robinia pseudoacacia forest. In spite of first two species are nowadays listed as invasive in the Slovak checklist of the alien flora (MEDVECKÁ et al., 2012) and were not considered here, presence of most of the rest species in the forest was temporary (except for Fraxinus pennsylvanica and Ilex aquifolium).

Further spreading of species originally planted in the Mlyňany Arboretum was hindered by inadequate conditions for their establishment and growth (forests, fields, abandoned vineyards with tall grass) and we usually met only fruit trees escaped from private gardens, like Prunus persica and Juglans regia. Moreover, their frequency decreased with distance from the villages.

Political changes in 90-ties of the 20th century (fall of the socialism) associated with a wide abandonment of the collective farms enabled a large escape of numerous plant species, Juglans regia being among them (PÁNDI et al., 2014; LENDA et al., 2018). However, in inner Alpine valleys infestation of forests by walnut started after 1970 , when winters became milder thanks to climate warming (LOACKER et al., 2007). On the other hand, this species frequently suffers from fungal pathogens Marssonia juglandis and Cerioporus squamosus in Slovakia, markedly affecting their growth and nut production (ZÚBRIK et al., 2019).

Occasional occurrence of common ornamental and fruit woody plants in the urbanised area of all three villages was isolated and represent a relatively low threat for natural habitats. Surprisingly, no spontaneous spreading of non-native species was observed in the historical aristocratic park of Nová Ves nad Žitavou. Substantially smaller area compared to the arboretum and adequate garden management can explain this observation.

Petřík et al. (2019) distinguished five distinct clusters among Czech settlements, which were based on the ornamental flora composition. Core species collection of the fourth cluster - old rustic settlements, best matching with our three-village cluster, contained following shrubs: Lonicera fragrantissima, L. × purpusii, Myrtus communis, Skimmia japonica, Syringa $\times$ chinensis, Viburnum farreri and $V . \times$ bodnantense. Despite different preferences of Slovak villagers concerning ornamental plantations, we did not record any massive escape in the urbanised area.

Most of the taxa frequently present (from hundreds of individuals up) in the three-village cluster originate in south-eastern Asia, were first introduced to the area of present Slovakia in 19th century, are/recently were widely planted in this country, disperses by animals and can tolerate shade and drought (Table 5).

According to PYŠEK et al. (2009), probability to escape of a woody plant species increases with residential time in a country and its planting intensity. On the other hand, naturalisation probability of trees/shrubs depends on year of the first introduction to Europe, origin (lower for those from Asia) and propagule size (lower for smaller ones). ArONSON et al. (2007) concluded that most successful aliens in New York metropolitan were broadleaf vines, shrubs and trees producing fleshy fruits. Mediterranean garden plants are prone to escape to old fields particularly when they prefer dry and slightly basic soils and are dispersed by animals (MARCO et al., 2010). All these works are in accordance with our observations.

However, only one from them can create an invasion risk on the national level - Amorpha fruticosa, which is regarded as naturalised in Slovakia (MEDVECKÁ et al., 2012). Czech catalogue of alien plants (PYŠEK et al., 2012) also indicates this species as naturalised. The same status it has in Austria (WALTER et al., 2005), Hungary (BorZA et al., 2020) and Poland (ToKARSKA-GUZIK et al., 2012) but it is invasive in Romania (Sîrbu and OpreA, 2011) and Ukraine (BUDRA and Koniakin, 2019). Nevertheless, continuous climate change, as manifested by higher temperatures and extended drought periods (in the studied area particularly in early spring (Figure 2)), can favour further woody plant species.

\section{Conclusions}

One tenth of cultivated non-native woody plant taxa spontaneously spreads in the Mlyňany Arboretum (particularly Cotoneaster spp., Prunus laurocerasus, Prunus serotina and Quercus rubra). Number of seedlings is positively correlated with the mother plant number. Almost one third of them escaped behind the fence but did not spread more than $500 \mathrm{~m}$ (mainly Mahonia aquifolium and Prunus serotina). Precise management of the historical aristocratic park in Nová Ves nad Žitavou prevented broader escape from culture. Private gardens are a large source only of Juglans regia seedlings but their concentration decreases with distance from villages. This study also shows actual spreading potential of numerous woody plant species in the SW Slovakia as well as assesses risk of their future invasiveness on the national level (Amorpha fruticosa was ranked as that with the highest invasive potential).

\section{Acknowledgement}

This work was supported by project of the Scientific Granting Agency of the Ministry of Education, Science, Research and Sport of the Slovak Republic, no. 2/0058/18.

\section{References}

Aronson, M.F.J., Handel, S.N., Clemants, S.E., 2007. Fruit type, life form and origin determine the success of woody plant invaders in an urban landscape. Biological Invasions, 9: 465-475.

BENČǍ̆, F., 1982. Atlas rozširenia cudzokrajných drevín na Slovensku a rajonizácia ich pestovania [Atlas of the distribution of exotic woody plants in Slovakia and zoning of their cultivation]. Bratislava: Veda. $456 \mathrm{p}$.

BenČaŤová, B., Koprda, J., BenČǍ̆, T., 2013. The shrub and black locust communities of chosen parts of the Hron downs, the Slovak Republic. Folia Oecologica, 40 (2): $157-162$. 
Borza, P., Csecserits, A., Balogh, L., Weiperth, A., Jenna Wong, L., Pagad, S., 2020. Global Register of Introduced and Invasive Species - Hungary. Version 1.2. Invasive Species Specialist Group ISSG. Checklist dataset. [online]. https://doi.org/10.15468/52jed5

Burda, R.I., Koniakin, S.N., 2019. The non-native woody species of the flora of Ukraine: introduction, naturalization and invasion. Biosystems Diversity, 27 (3): 276-290. https://doi.org/10.15421/011937

Bomanowska, A., Kurzac, M., StefaniaK, A., 2012. Floristic diversity of plants spontaneously spreading in the botanical garden of the University of Łódź (Poland). Biologica Nyssana, 3 (1): 1-10.

ChocholoušKová, Z., PYšEK, P., 2003. Changes in composition and structure of urban flora over 120 years: a case study of the city Plzeň. Flora, 198: 366-376.

Dehmen-Schmutz, K., Touza, J., Perrings, C., WilliamSON, M., 2007. A century of the ornamental plant trade and its impact on invasion success. Diversity and Distribution, 13: 527-534.

ELIÁš, P. JR., 2017. Zaujímavejšie floristické nálezy [Interesting floristic findings]. Bulletin Slovenskej Botanickej Spoločnosti, 39 (2): 204-217.

FAŠKO, P., LAPIN, M., PeChO, J., 2008. 20-year extraordinary climatic period in Slovakia. Meteorologický časopis, 11: 99-105.

Ferus, P., HoŤKa, P., KonôPKová, J., 2017a. Drought and frost tolerance in rhododendron collection of the Mlyňany Arboretum (Slovakia): a screening for future climate. $\mathrm{FO}_{\mathrm{O}}$ lia Oecologica, 44: 87-95.

Ferus, P., Hrubík, P., Zahradníková, E., Konôpková, J., HoŤKA, P., TuRČEKová, M., 2017b. Zrkadlenie času vo výskume allochtónnej dendroflóry v Arboréte Mlyňany SAV [Time mirroring in the Mlyňany Arboretum's research of allochtonous dendroflora]. In FiLoví, A. (ed.). Arborétum Mlyňany včera a dnes. Zbornik prednášok $z$ odborného seminára $k 125$. výročiu založenia arboréta. Arborétum Mlyňany 16. november 2017. Vieska nad Žitavou: Ústav ekológie lesa SAV, DP Arborétum Mlyňany, p. 42-52.

Godefroid, S., Phartyal, S.S., Weyembergh, G., Koedam, N., 2005. Ecological factors controlling the abundance of non-native invasive black cherry (Prunus serotina) in deciduous forest understory in Belgium. Forest Ecology and Management, 210: 91-105.

Granec, M., Šurina, B., 1999. Atlas pôd SR [The soil atlas of the Slovak Republic]. Bratislava: Výskumný ústav pôdoznalectva a ochrany pôdy. $60 \mathrm{p}$.

Guo, W.-Y., van Kleunen, M., Pierce, S., Dawson, W., Essl, F., Kreft, H., Maurel, N., Pergl, J., Seebens, H. Weigelt, P., PyšEK, P., 2018. Domestic gardens play a dominant role in selecting alien species with adaptive strategies that facilitate naturalization. Global Ecology and Biogeography, 28: 628-639.

Halarewicz, A., Zolnierz, L., 2014. Changes in the understorey of mixed coniferous forest plant communities dominated by the American black cherry (Prunus serotina Ehrh.). Forest Ecology and Management, 313: 91-97.

Hulme, P.E., Bacher, S., Kenis, M., Klotz, S., Kühn, I., Minchin, D., Nentwig, W., Olenin, S., Panov, V., Per-
GL, J., PYŠEK, P., Roques, A., Sol, D., Solarz, W., Vilà, M., 2008. Grasping at the routes of biological invasions: a framework from integrating pathways into policy. Journal of Applied Ecology, 45: 403-414.

Hulme, P.E., 2011. Addressing the threat to biodiversity from botanic gardens. Trends in Ecology and Evolution, 26 (4): 168-174.

KOWARIK, I., 2005. Urban ornamentals escaped from cultivation. In Gressel, J. (ed.). Crop ferality and volunteerism. CRC Press, p. 97-121.

KŘıv́́NeK, M., PYŠEK, P., 2006. Predicting invasions by woody species in a temperate zone: a test of three risk assessment schemes in the Czech Republic (Central Europe). Diversity and Distribution, 12: 319-327.

KŘIVÁNEK, M., PYŠEK, P., 2008. Forestry and horticulture as pathways of plant invasions: a database of alien woody plants in the Czech Republic. In ToKarska-GuziK, B., Brock, J.H., Brundu, G., Child, L., Daehler, C.C., PYšEK, P. (eds). Plant invasions: human perception, ecological impacts and management. Leiden: Backhuys Publishers, pp. 21-38.

Lenda, M., Knops, J.H., Skórka, P., Moroń, D., WoyCIECHOWSKI, M., 2018. Cascading effect of changes in land use on the invasion of the walnut Juglans regia in forest ecosystems. Journal of Ecology, 106: 671-686.

Loacker, K., Kofler, W., Pagitz, K., Oberhuber, W., 2007. Spread of walnut (Juglans regia L.) in an Alpine valley is correlated with climate warming. Flora - Morphology, Distribution, Functional Ecology of Plants, 202 (1): 70-78.

Lososoví, Z., ChytrÝ, M., TichÝ, L., Danihelka, J., FAJMon, K., HájeK, O., Kintrová, K., KüHN, I., LÁNíková, D., OTÝPKOvá, Z., ŘEHOŘEK, V., 2012. Native and alien floras in urban habitats: a comparison across 32 cities of central Europe. Global Ecology and Biogeography, 21: 545-555.

Marco, A., Lavergne, S., Dutoit, T., Bertaudiere-Montes, V., 2010. From the backyard to the backcountry: how ecological and biological traits explain the escape of garden plants into Mediterranean old fields. Biological Invasions, 12: 761-779.

Mayr, K., Haeuser, E., Dawson, W., Essl, F., Kreft, H., Pergl, J., Pyšek, P., Weigelt, P., Winter, M., Lenzner, B., van KLEUnen, M., 2017. Naturalization of ornamental plant species in public green speces and private gardens. Biological Invasions, 19: 3613-3627.

Medvecká, J., Kliment, J., Májeková, J., Halada, L., ZALiberová, M., Gojdičová, E., FeráKová, V., Jarolímek, I., 2012. Inventory of the alien flora of Slovakia. Preslia, 84: 257-309.

Nagodă E., Comănescu P., Anastasiu, P., 2014. „Dimitrie Brandza" Botanic Garden, potential centre for the dispersal of invasive plants? Acta Horti Botanici Bucurestiensis, 41 (1): 13-40. doi: 10.2478/ahbb-2014-0002

Pándi, I., Penksza, K., Botta-Dukát, Z., Kröel-Dulay, G., 2014. People move but cultivated plants stay: abandoned farmstaeds support the persistence and spread of alien plants. Biodiversity Conservation, 23: 1289-1302.

Petřík, P., SÁdlo, J., Hejda, M., Štajerová, K., PyšEk, P., Pergl, J., 2019. Composition patterns of ornamental flora in the Czech Republic. NeoBiota, 52: 87-109.

Pheloung, P.C., Williams, P.A., Halloy, S.R., 1999. A weed 
risk assessment model for use as a biodiversity tool evaluating plant introductions. Journal of Environmental Management, 57: 239-251.

Polláková, N., Šimanský, V., JonczaK, J., 2017. Characteristics of physical properties in soil profiles under selected introduced trees in the Nature reserve Arboretum Mlyňany, Slovakia. Folia Oecologica, 44: 78-86.

PYŠEK, P., KŘIVÁNEK, M., JAROŠíK, V., 2009. Planting intensity, residence time, and species traits determine invasion success of alien woody plants. Ecology, 90 (10): 2734-2744.

PYšeK, P., Jarošík, V., Pergl, J., 2011. Alien plants introduced by different pathways differ in invasion success: unintentional introductions as a threat to natural areas. PLOS ONE, 6 (9): e24890.

Pyšek, P., Danihelka, J., Sádlo, J., Chrtek, J., Chytrí, M., Jaroší, V., Kaplan, Z., Krahulec, F., Moravcová, L., Pergl, J., Štajerová, K., TichÝ, L., 2012. Catalogue of alien plants of the Czech Republic (2nd edition): checklist update, taxonomic diversity and invasion patterns. Preslia, 84: 155-255.

REHDER, A., 1954. Manual of cultivated trees and shrubs hardy in North America: exclusive of the subtropical and warmer temperate regions New York: MacMillan. 996 p.

SCHMIDT, G., 2001. Exotic woody plants inclining to escape in the Buda Arboretum under strong urban effect in Budapest. International Journal of Horticultural Science, 7(3-4): 93-97.

Schrader, G., StARFinger, U., 2009. Risk analysis for alien plants in European forests illustrated by the example of Prunus serotina. In Kohli, R.K., Jose, S., Singh, H.P., BATISH, D.R. (eds). Invasive plants and forest ecosystems. Boca Raton, London: CRC Press, Taylor \& Francis Group, p. 196-215.

SHYNDER, O.I., 2019. Spontaneous flora of M. M. Gryshko National Botanical Garden of the NAS of Ukraine (Kyiv). 3. escaped plants. Plant Introduction, 3: 14-29.

Sîrbu, C., OpreA, A., 2011. Plante adventive în flora României [Alien plants in the Romanian flora]. Iaşi: Editura Ion Ionescu de la Brad. 733 p.

Theoharides, K.A., Dukes, J.S., 2007. Plant invasion across space and time: factors affecting nonindigenous species success during four stages of invasion. New Phytologist, 176: 256-273.

Tokarska-Guzik, B., Dajdok, Z., ZająC, M., ZająC, A., Urbisz, A., Danielewicz, W., HoŁdyŃski, C., 2012. Rośliny obcego pochodzenia w Polsce ze szczególnym uwzględnieniem gatunków inwazyjnych [Alien plants in Poland with particular reference to invasive species]. Warszawa: Generalna Dyrekcja Ochrony Środowiska. $197 \mathrm{p}$.

TомAŠKO, I., 1999. Invázne dendrotaxóny Arboréta Mlyňany [Alien woody plant taxa of the Mlyňany Arboretum]. In Eliáš, P. (ed.). Invázie a invázne organizmy 2. Zbornik príspevkov $z$ vedeckej konferencie. Nitra, 18. - 20. novembra 1998. Nitra: Slovenský národný komitét SCOPE, Slovenská ekologická spoločnost' pri SAV, p. 183-190.

Tomaško, I., 2004. Historické parky a okrasné záhrady na Slovensku [Historical parks and ornamental gardens of Slovakia]. Bratislava: Veda. 158 p.

Van Kleunen, M., Essl, F., Pergl, J., Brundu, G., Carboni, M., Dullinger, S., Early, R., Gonzalez-Moreno, P., Groom, Q.J., Hulme, P.E., KuefFer, C., KüHN, I., MAguas, C., Maurel, N., Novoa, A., Parepa, M., Pysek, P., Seebens, H., Tanner, R., Touza, J., Verbrugge, L., Weber, E., Dawson, W., Kreft, H., Weigelt, P., Winter, M., Klonner, G., Talluto, M.V., Dehnen-SchmuTZ, K., 2018. The changing role of ornamental horticulture in alien plant invasions. Biological Reviews, 93 (3): 1421-1437.

Walter, J., Essl, F., Englisch, T., Kiehn, M., 2005. Neophytes in Austria: habitat preferences and ecological effects. In Nentwig, W., Bacher, S., Cock, M.J.W., Dietz, H., Gigon, A., Wittenberg, R. (eds). Biological invasions: from ecology to control. NeoBiota, vol. 6. Berlin: NEOBIOTA, p. 13-25.

WALTER, V., 2011. Rozmnožování okrasných stromů a keřu [Propagation of ornamental trees and shrubs]. Praha: Brázda. 312 p.

Zerbe, S., 2007. Non-indigenous plant species in central European forest ecosystems. In Hong, S.- K., Nakagoshi, N., Fu, B.J., Morimoto, Y. (eds). Landscape ecological applications in man-influenced areas: linking man and nature systems. Dordrecht: Springer, p. 235-252.

Zúbrik, M., Kunca, A., Kunca, A., Vakula, J., Galko, J., LeontovyČ, R., KonôPKa, B., GubKa, A., Nikolov, Ch., Rell, S., Longauerová, V., Malová, M., CsóKa, G., 2019. Atlas poškodení lesných drevín: hmyz a huby [Atlas of the forest tree damage: insects and fungi]. Zvolen: Národné lesnícke centrum - Lesnícky výskumný ústav, $244 \mathrm{p}$.

Received May 7, 2020

Accepted September 30, 2020 